Annals of Warsaw University of Life Sciences - SGGW

Land Reclamation No 42 (2), 2010: 295-302

(Ann. Warsaw Univ. of Life Sci. - SGGW, Land Reclam. 42 (2), 2010)

\title{
Saturation criteria for heavy overconsolidated cohesive soils
}

\author{
MIROSŁAW J. LIPIŃSKI, MAŁGORZATA WDOWSKA \\ Department of Geotechnical Engineering, Warsaw University of Life Sciences - SGGW
}

\begin{abstract}
Saturation criteria for heavy overconsolidated cohesive soils. The paper concerns significance of properly carried out saturation procedure and its role in evaluation of undrained response of heavy preconsolidated cohesive soils. In particular the saturation criteria are addressed which should be fulfilled during saturation of preconsolidated clay specimens of various plasticity. Influence of incomplete saturation on shear strength parameters is briefly characterized. On the basis of experimental data the back pressure method is shown to be the most efficient method in obtaining full saturation in overconsolidated clay of various plasticity. Analysis of the test results made possible to propose full saturation criteria for low, medium and high plasticity clays which are based on reduced value of Skempton's $B$ parameter.
\end{abstract}

Key words: cohesive soils, saturation criteria, traixial test, errors.

\section{INTRODUCTORY REMARKS}

One of the major assumptions made during standard triaxial tests is that during consolidation as well as in the course of shearing, degree of saturation $\mathrm{S}_{\mathrm{r}}$ is equal to 1 . When the full saturation is reached then boundary conditions with respect to stresses can be controlled. Knowing total stresses and having reliable value of pore pressure allows to make use of effective stress principle:

$\sigma^{\prime}=\sigma-\mu$
Unfortunately, in practice the requirement concerning full saturation is rarely accomplished. In Poland it concerns commercial as well as university laboratories. Assembled specimens are very often not saturated or water is only flushed through them. Even in material having higher permeability, flushing with water alone does not guarantee full saturation. Effective stresses are calculated by subtracting pore pressure transducer reading from total stress. Certainly this have nothing in common with proper determination of undrained response of soil to loading.

Independently of the consequences of such situation, which will be addressed in the further paragraphs of this paper, due to a large scale of this phenomenon it is worth to analyse its reasons. One of the most feasible explanation for this is that in the past, majority of triaxial tests were carried out on soft soils, very often prepared in the laboratory. In such situation, full saturation of a soil might be a result of sample preparation procedure. In case of natural soils, especially cohesive and heavy overconsolidated, making assumption that material is fully saturated is highly non realistic. Besides, it violates the major principle in experimental research according to which each assumption concerning any element of the test should be experimentally verified. 
In the further part of the paper, the back pressure method was described as a useful tool for saturation of stiff soils, and test results on heavy overconsolidated cohesive soils of various plasticity were presented upon which some saturation criteria were proposed.

\section{INFLUENCE OF $S_{R}$ ON EVALUATION OF SHEAR STRENGTH PARAMETERS}

Effective stress is calculated on the basis of pore pressure value which to large extent depends on degree of saturation. Not full saturation of soil influences shape of effective stress path and as a consequence a value of undrained shear strength. It is schematically illustrated in Figure 1, where stress paths for fully saturated and not fully saturated soil are compared. It results from the Figure 1a that pore pressure changes are entirely different in the two of analyzed cases. Thus effective stress paths as well as actual value of undrained shear strength differ significantly. For normally consolidated and slightly overconsolidated soils, as shown in Figure 1a, value of undrained shear strength for not fully saturated material is considerably overestimated. Range of error which is shown for single test in
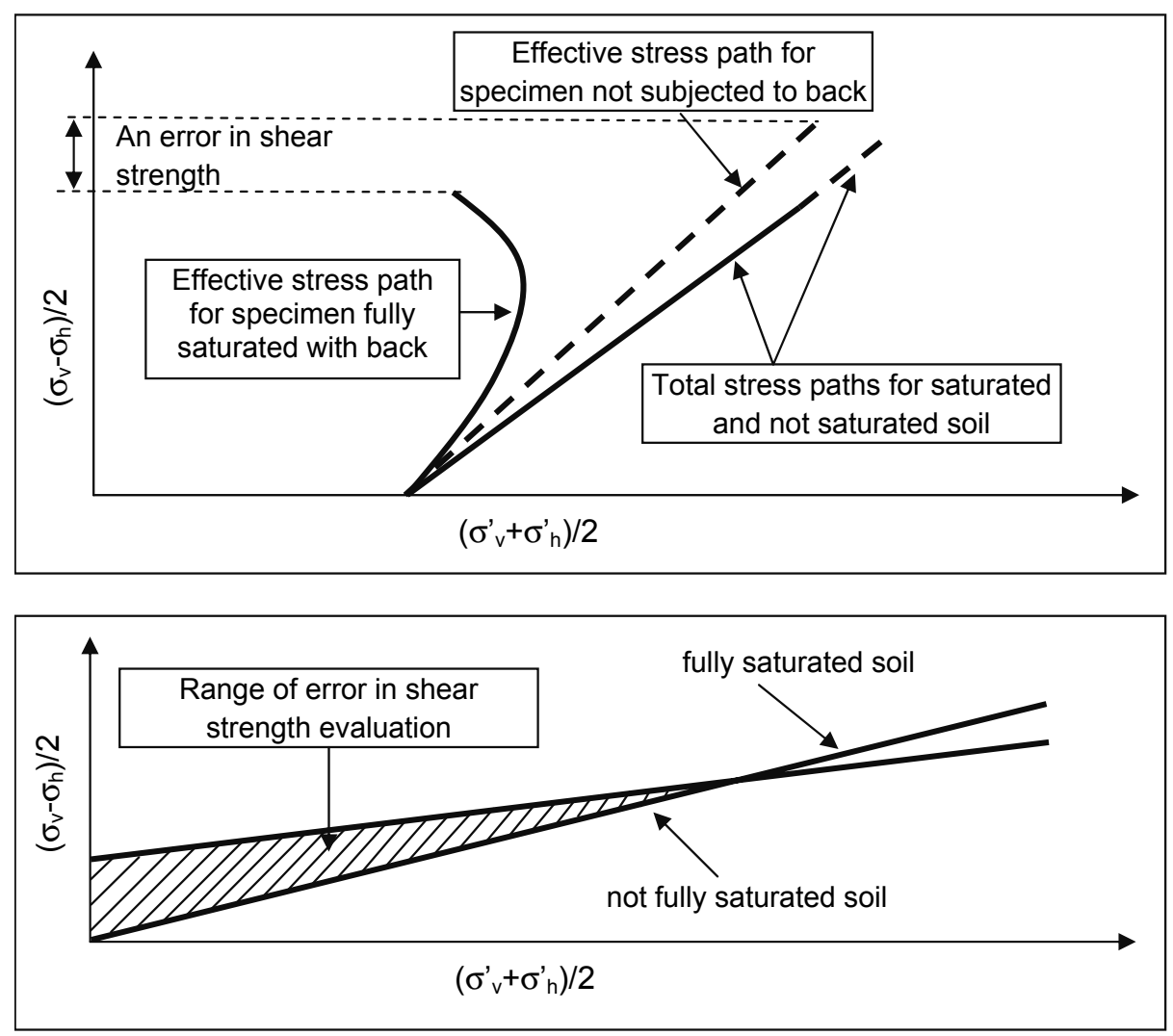

FIGURE 1. An error in shear strength evaluation due to not full saturation 
Figure 1a changes with respect to mean effective stress. This change is shown schematically in Figure 1b. The Figure explicitly shows that shear strength envelopes for fully and not fully saturated material differ significantly. A value of shear strength is overestimated for small and intermediate normal stress mostly encountered in majority of practical problems, which also results from Figure 1. When stresses become higher an error becomes smaller because degree of saturation increases due to decrease in void ratio value. For high stress, shear strength expressed by angle of internal friction and cohesion intercept is underestimated. An error resulting from not full saturation in each case depends on soil kind, initial value of degree of saturation and on stress history of a soil. The last factor determines undrained response of soil during shearing, because pore pressure change depends on acquired stress history. Not full saturation substantially changes pore pressure increase and thus underestimates it in case of contractive samples and overestimates it in case of dilative response.

It should be also noticed that in case of drained shearing not full saturation changes some of characteristics obtained during a test. It refers to volume change from which some very important characteristics are derived like dilatancy angle or (not directly) Poisson's ratio. It might also change value of deformation modulus.

\section{SATURATION BY BACK PRESSURE METHOD}

In laboratory practice full saturation of soil during triaxial test is usually realized with use of back pressure method. In Po- land the term "back pressure" is very often translated incorrectly ("ciśnienie wsteczne" or "przeciwciśnienie"). It results from not understanding the merit of the method and direct translation of single words. In Polish the term "back pressure method" should be translated as "ciśnienie wyrównawcze" as it reflects the principle of the method. The back pressure method is based on two physical rules ie. Boyle's low describing compressibility of fluid and Henry's low concerning solubility of gas in water due to high pressure application. The method rests on simultaneous rising pressure in triaxial cell as well as in a specimen, thus effective stress acting on a specimen remains constant. At the same time elevated pressure applied to a soil dissolves air remaining in pores of a specimen. The major advantage of this method rests in the fact that soil specimen can be saturated without any changes of effective stress which determines any change of soil state. The second advantage of the method results from possibility of monitoring saturation process at every stage of cell and back pressure increments. Progress in saturation is based on pore pressure response to applied total stress application and uses Skempton's equation (1954) in the following form:

$$
\Delta u=B\left[\Delta \sigma_{3}+A\left(\Delta \sigma_{1}-\Delta \sigma_{3}\right)\right]
$$

$\Delta \mathrm{u}$-pore pressure increment,

A and B - parameters in Skempton's equation,

$\Delta \sigma_{1}, \Delta \sigma_{3}-$ total principal stress increments.

When vertical and horizontal stress increments are equal then degree of 
saturation can be determined on the basis of $\mathrm{B}$ parameter which correlates quite well with $\mathrm{S}_{\mathrm{r}}$. Before application of subsequent stress increment $B$ value is checked. Stress increments used in each stage can be increased upon progress in saturation visualized by higher B value. During staged process of saturation no strain is allowed to appear and effective stress remains constant. The last stage of pressure increase determines value of back pressure at which consolidation and shearing stage (if drained) are tested.

\section{RESULTS FOR OVERCONSOLIDATED COHESIVE SOILS}

Application of water under pressure into pores of not fully saturated soil increases its degree of saturation. Value of back pressure necessary to increase degree of saturation from its initial value $S_{r 0}$ to another required $\mathrm{S}_{\mathrm{r}}$ had been described by Lowe and Johnson (1960) in the following form:

$$
\Delta u=p_{0} \frac{\left(S_{r}-S_{r 0}\right)(1-H)}{1-S_{r}(1-H)}
$$

$\Delta \mathrm{u}$ - back pressure increment $[\mathrm{kPa}]$

$\mathrm{S}_{\mathrm{r}}$ - degree of saturation,

$\mathrm{S}_{\mathrm{r} 0}$ - initial degree of saturation,

$\mathrm{p}_{0}$ - atmospheric pressure, (assumed

$101.33 \mathrm{kPa})$

$\mathrm{H}$ - Henry's constant (assumed as 0.02 $\mathrm{ccm}$ of gas on $1 \mathrm{ccm}$ of water at temperature $20^{\circ} \mathrm{C}$ ).
Values of pressure calculated on the basis of this equation can reach very high level. For instance, for initial degree of saturation $\mathrm{S}_{\mathrm{r} 0}=0.8$, value of back pressure required to achieve full saturation reaches $1000 \mathrm{kPa}$. In every day laboratory practice so elevated values of back pressure are not used. Moreover, in each kind of soil a process of saturation is different. This statement does not refer only to soil kind but also to its stress history. For this reason it is important to carry out tests on overconsolidated soils of various plasticity in order to obtain relationship among back pressure, degree of saturation and Skempton's parameter B.

As the first step to obtain such relationship charts shown in Figure 2 can be considered. The charts presents Skempton's parameter B against applied back pressure for two kinds of cohesive oveconsolidated soils ie. low plasticity clay and high plasticity clay. Values of plasticity index PI and liquidity index LI for each test are included in the legend. Test results explicitly show that saturation process strongly depends on plasticity and state of soil and also that values of back pressure necessary to achieve required $\mathrm{B}$ parameter are considerable higher for high plasticity clays than for low plasticity clays. It also results from the charts that initial values of B (ie. after flushing and prior application of back pressure) are very low and usually do not exceed 0.2. This observation leads to important conclusion that overconsolidated cohesive soils which are not subjected to back pressure saturation procedure are not saturated even if they were flushed with water in a triaxial cell. 

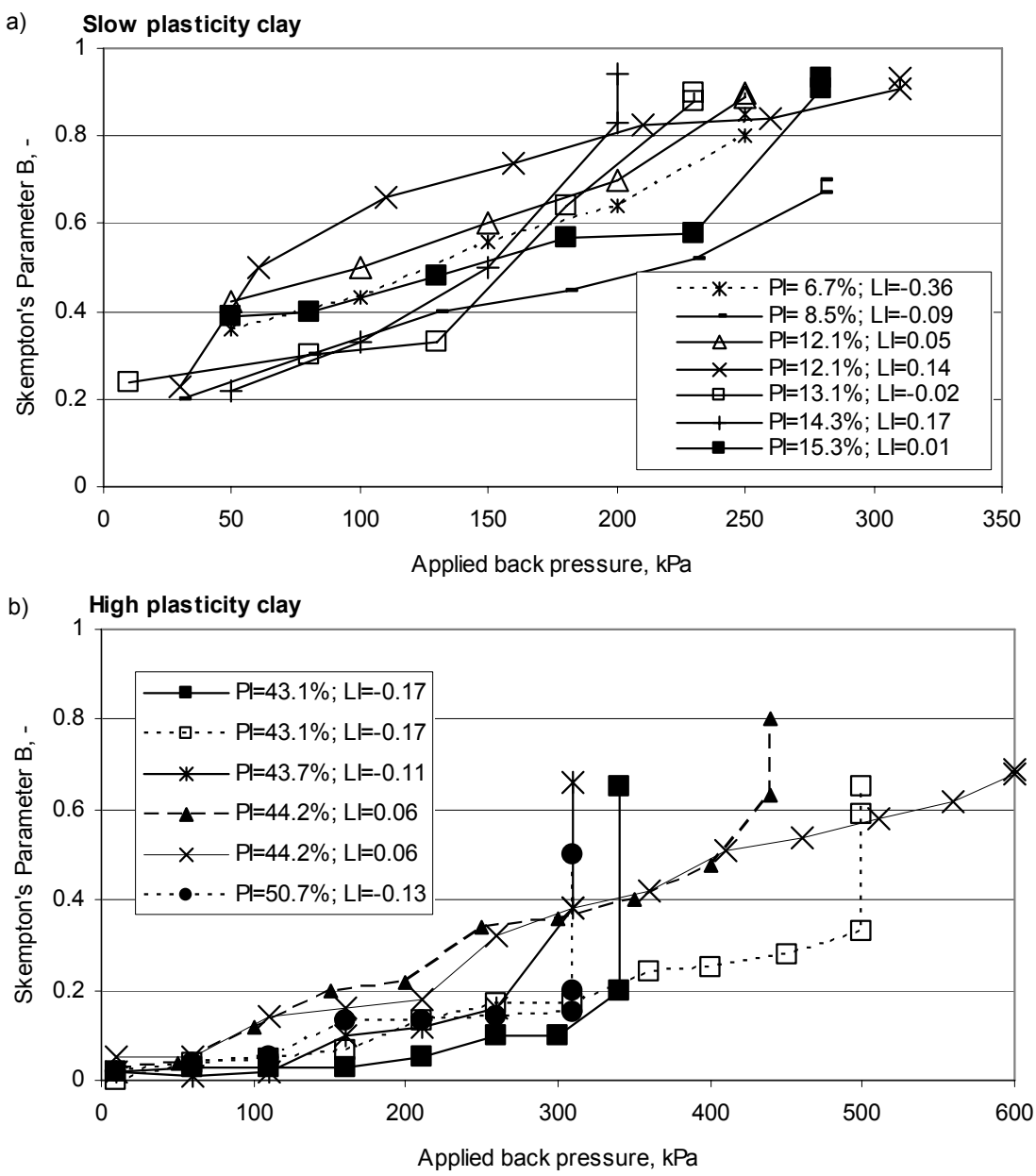

FIGURE 2. Change in Skempton's Parametr B due to applied back pressure: a) low plasticity clay, b) high plasticity clay

\section{ANALYSIS OF THE DATA}

Taking into account values of back pressure applied during tests which results are shown in Figure 2 and putting them into equation (3) and rearranging it, one can obtain formula from which values of degree of saturation achieved at the end of saturation process can be calculated:

$$
S_{r}=\frac{p_{0} S_{r 0}-\frac{\Delta u}{H-1}}{\Delta u+p_{0}}
$$

To each calculated value of $S_{r}$, corresponding value of Skempton's parameter $\mathrm{B}$ measured during test can be assigned. Accounting for all stages during satura- 
tion one can get correlation between B three kinds of soil ie. low, medium and parameter and degree of saturation. In high plasticity clays. A slightly similar Figure 3 such correlations are shown for characteristics were published by Black
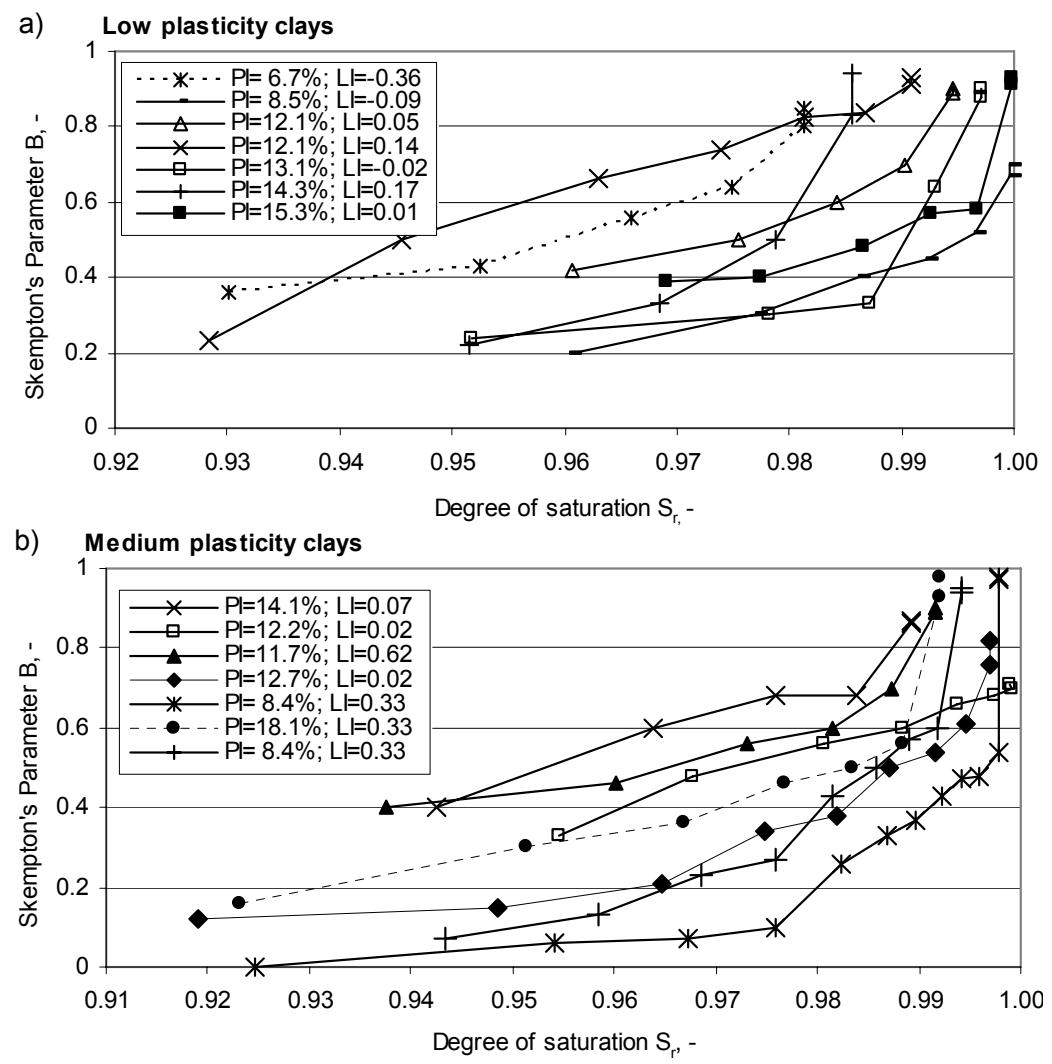

c) High plas ticity clays

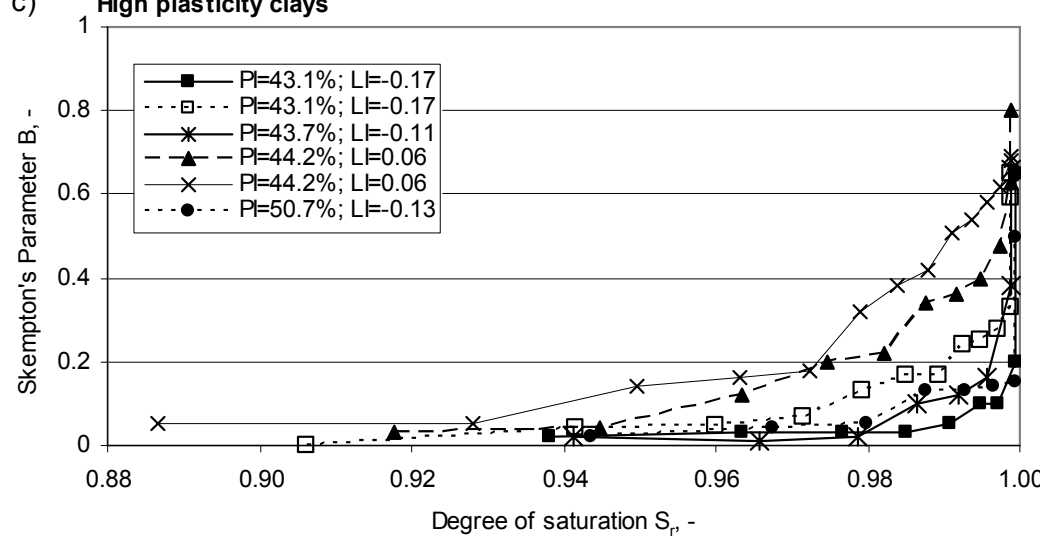

FIGURE 3. Skempton's parameter B against degree of saturation for overconsolidated clays of various plasticity 
and Lee (1973), however their relationship were of general character, not for real soils.

Charts shown in Figure 3 explicitly reveal that relationships between $\mathrm{B}$ parameter and degree of saturation strongly depends on plasticity of overconsolidated soil. It might be also deduced from these charts that value of $B$ parameter reflects to a certain degree state of soil quantified by liquidity index. Weaker the soil (ie. higher liquidity index value) bigger $\mathrm{B}$ value for the same degree of saturation. In order to draw some generalized conclusion one can calculate average values for each kind of soil thus unique characteristic for each soil can be generated. In Figure 4 such characteristics for low, medium and high plasticity clays are shown. These three relationships clearly indicate that criteria of recognizing full saturation based on Skempton's parameter B should be different for various kind of overconsolidated cohesive soils. On the basis of the data shown in Figure 4 one can derived values of minimum B value achievement of which can be considered as equivalent of full saturation of the soil. For considered kind of soil minimum B values are as follow:

- Low plasticity clays 0.8

- Medium plasticity clays

- High plasticity clays 0.4

These recommendations are very important since they can be treated as an alternative to rigorous requirement of achievement $B=1$. Such rigorous criterion for heavy overconsolidated cohesive soil is not justified rationally and also is not practical since requires very high pressures. The above criteria for full saturation of heavily overconsolidated cohesive soils of various plasticity can be considered as recommended values, at least in commercial laboratories. The major rational for that is that undrained response of soils having such $\mathrm{B}$ value before shearing is not changed comparing to soils saturated with very high $(>800$ $\mathrm{kPa}$ ) back pressure.

\section{SUMMARY AND CONCLUSIONS}

The major premise for recalling the subject discussed in the paper was to draw the attention on importance of labora-

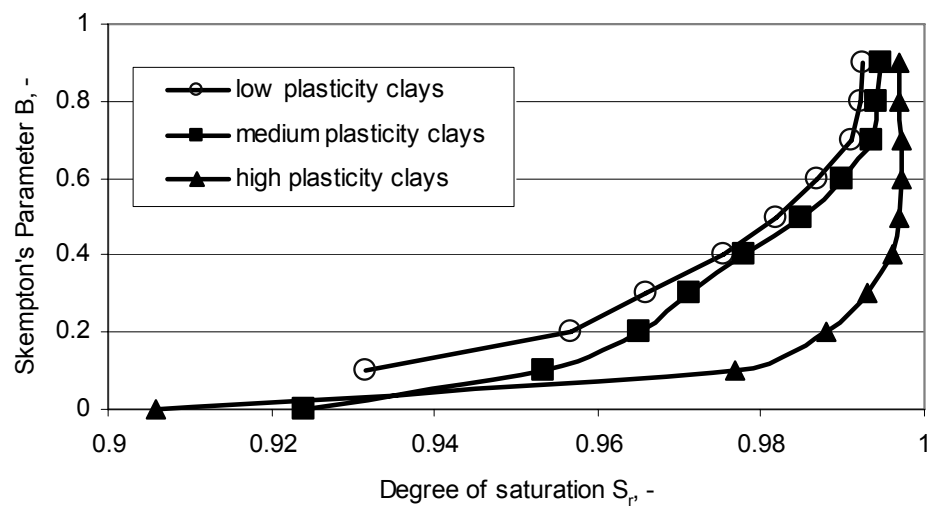

FIGURE 4. Average relationship between Skempton's parametr B and degree of saturation for overconsolidated clays of various plasticity 
tory saturation procedure as a key factor controlling quality of triaxial test. It was shown that lack of full saturation is one of the most important factor for overestimation of shear strength. Back pressure saturation procedure was shown to be efficient tool to help in improvement of triaxial test quality.

Tests on three kinds of overconsolidated cohesive soil ie. low medium and high plasticity clays were used to work out criteria for full saturation based on Skempton's parameter B measured prior to shearing. These value are respectively to soil kind $0.8,0.7$ and 0.4 . Achievement of these values in specified soils guarantee no alternation in response of soil during undrained shearing.

\section{Acknowledgment}

Some parts of experimental work were supported by Ministry of Science and Higher Education within the project NN506098933 in the period 2007-2010.

Streszczenie: Kryteria pelnego nasycenia dla gruntów spoistych silnie prekonsolidowanych. Jednym z najczęściej popełnianych błędów w laboratoryjnych badaniach właściwości mechanicznych gruntu jest niekontrolowany stan nasączenia gruntów. Artykuł dotyczy kryteriów, jakie powinny być spełnione podczas nasączania próbek różnych gruntów w badaniach trójosiowych. W pracy scharakteryzowano wpływ niepełnego wypełnienia porów gruntu wodą na błędy uzyskiwane w wynikach badań. Przedstawiono metodę ciśnienia wyrównawczego jako najbardziej skuteczny sposób doprowadzenia do pełnego nasycenia gruntu. Zaprezentowano wyniki badań dla prekonsolidowanych gruntów spoistych o różnej spoistości, tj. glin piaszczystych, glin i iłów. Analiza tych wyników pozwoliła na określenie minimalnych wartości parametru Skemptona B dla tych gruntów jakie powinny być spełnione dla otrzymania prawidłowej (niezafałszowanej) reakcji gruntu podczas ścinania w warunkach bez odpływu.

Stowa kluczowe: grunty spoiste, kryteria pełnego nasycenia, badanie trójosiowe, błędy.

\section{REFERENCES}

BLACK D.K., LEE K.L. 1973: Saturating laboratory samples by back pressure.Journal of Soil Mechanics and Foundations Division ASCE 99, No SM1, 75-93.

LOWE J., JOHNSON T.C. 1960: Use of back pressure to increase degree of saturation in triaxial test specimens. ASCE Conf. on Shear Strength Cohesive Soils, Boulder, Colorado. USA, 819-836.

SKEMPTON A.W. 1954: The pore pressure coefficients A and B, Geotechnique 4, 143-147.

MS. received November 15, 2010

\author{
Authors' address: \\ Wydział Inżynierii i Kształtowania Środowiska \\ SGGW \\ Katedra Geoinżynierii \\ 02-787 Warszawa \\ ul. Nowoursynowska 166 \\ Poland \\ miroslaw_lipinski@sggw.pl \\ malgorzata_wdowska@sggw.pl
}

